\title{
Jordanian EFL Students' Attitudes Toward Using World Wide Web Net and Its' Effect on their Linguistic Proficiency
}

\author{
Abeer Al-Ghazo* \\ Ajloun National University, Ajloun, Jordan
}

Corresponding Author: Abeer Al-Ghazo, E-mail: fares.abeer@yahoo.com

\begin{tabular}{l} 
ARTICLE INFO \\
\hline Article history \\
Received: November 12, 2017 \\
Accepted: January 28, 2018 \\
Published: March 01, 2018 \\
Volume: 7 Issue: 2 \\
Advance access: February 2018 \\
\hline
\end{tabular}

Conflicts of interest: None Funding: None

\begin{abstract}
This study aimed to investigate the attitudes of Jordanian EFL learners toward using the World Wide Web net for language learning proficiency. Another aim of this study was to explore whether there was any significant difference between males and females' attitudes toward using it. $40 \mathrm{EFL}$ learners (19 male and 21 female) studying English at Ajloun National University (ANU) in the first semester of the academic year 2016/2017 participated in the study. The researcher used an attitudinal questionnaire toward using WWW as an instrument. After collecting the data, SPSS software (version 20) was used to get the numerical interpretable information. An independentsample T-test was used to compare the results of the control and experimental groups. The results revealed that most of the participants in the study showed positive attitudes about the importance of using the World Wide Web net to develop their linguistic proficiency in the four language skills. Moreover, the results of T-test showed that there was no difference between female and male learners' attitudes toward the use of the internet for developing their language proficiency.
\end{abstract}

Key words: Jordanian EFL Learners, Attitudes, WWW, Proficiency, EFL Students, Linguistic Proficiency

\section{INTRODUCTION}

Language teaching and language learning are essential paradigms in the field of education which look at language as a vital mean of communication. Language has many different functions. It promotes learners to acquire knowledge and skills; expresses their own opinions and ideas about different topics in their life, sends and receive messages effectively, encourages a real language proficiency instead of just learning set of grammatical rules or acquiring vocabulary; arrange field trips and interpersonal approaches; and takes into account many variables relating to the nature of the learner, and the learning and teaching process, Raimes (1983). World Wide Web net has the great chance to play an important role in each of these fields and areas.

In recent researches, many studies focus on the importance and effectiveness of the using worldwide web (WWW) on EFL students' language proficiency. In any classroom learning practices, EFL students vary in cognitive and emotional factors that have a very close relationship with their practices and performance such as motivation, perceptions, attitudes, self-efficiency, learning style, and their levels of proficiency.

Attitudes are an important concept and factor to understand any person behavior. Gardner (1985, p. 10) defines attitudes as "the combination of effort plus desire to achieve the goal of learning plus favorable attitudes towards learning the language". Matsuda (2000) stated that "attitude" has three components: affective, cognitive, and behavior. The cognitive component refers to peoples' thoughts, their beliefs, and values about the language; the affective component refers to our feelings about the language; and the behavior component refers to our behavioral purpose to plan any action.

More recent research (Eagly \& Chaiken 1993;Ajzen \& Fishbein, 2000) indicates that attitudes described both internal and external dimensions. These dimensions are related to many psychological aspects such as likeable-dislikeable, good-bad, and pleasant-sad. We can see that attitudes refer to one's perceptions of objects favorably or unfavorably. Wu (2010) stated that attitude is one of the vital factors, which leads to the language achievement and performance of EFL proficiency. Gardner (2007) believes that learners, who have a high motivation, have a desire and a pleasure to learn the language effectively. In other words, learners should be motivated to use and speak the language in order to learn it effectively

Another major factor that determines learners' language performances is language proficiency. Ommagio (2001) defined 'proficiency' as the improvement and development of language performance and competence through the use of the language. Proficiency refers to the appropriate knowledge of any utterance to a particular content and context and. Stern (1983,)also maintained that either first, second or 
foreign language competence or proficiency can be summarized as:

"1-the intuitive mastery of the form of the language;

2- The intuitive mastery of the linguistic, cognitive, affective, and sociocultural meaning expressed by the language forms;

3-the capacity to use the language with maximum attention to communication and minimum attention to form; and

4-the creativity of language use." (p.364)

Many studies such as Brinton (2004), Lee (2004) and Mahboob, (2004) revealed that there are many factors underlying linguistic proficiency tests. These factors related to the main language skills. These skills are listening and reading, speaking comprehension, writing competence, vocabulary and structure. Although Language proficiency level is not always easy to define, many attempts have been made to improve language proficiency in a variety of ways. One of these ways is using the internet. Through the internet, the language learners can read, write, listen and talk about many topics and issues with the native speaker of English and can even develop their language proficiency.

American Council on the Teaching of Foreign Languages ACTFL (2012), indicates that foreign language proficiency refers to what an individual can do with language in terms of essential four skills (speaking, writing, listening, and reading) in real contexts and situations. That means proficiency is the application and assessment of acquiring these skills. These skills can be described in the following way. Listening: it is the ability to listen and view to understand English in a variety of authentic format and contexts. Speaking: It is the ability to use oral language properly and effectively to participate in discussions and present information in various authentic contexts. Reading: it is the ability to comprehend texts and read to understand and respond to written English in a variety of advanced authentic and literary contexts. Writing: It is the ability to produce written texts, to transfer the writer's information and ideas clearly in a variety of academic contexts. Those learners who master these language skills are expected to be proficient at English as a foreign language. The researcher thinks that the use of the internet may help in developing the learners' linguistic proficiency. Many researches (Kim, 2002; Teo, 2008) indicated that there is a positive correlation between students' attitudes towards WWW and theirperformance in the classroom. In other words, those who have more positive attitudes towards using internet, the more likely they are to use it to develop their linguistic proficiency. WWW is one of the most important media in all fields. It is considered as an international network in the field of language teaching and learning. It enables the learners to gain information from different sources, to do research, to process information, to communicate around world, to analyze and work with one another through many programs that the internet has such as social networking service and chatting. Many studies reported that using internet improved the students' linguistic proficiency. Internet provides students with an interactive learning experiences because it increases our students awareness of language, develops their vocabulary, provides them with a variety of language activities, enhances motivation and their oral proficiency (Lee, 2004, Hampel \& Hauck, 2004; Rossade, Heins \& Hampel, 2005). For example, the spread of internet chatting rooms may help the students, who learn English as a foreign language, in developing their language when they are engaged in communication with native speakers of English.

In this field, Coverdale-Jones, (2000) stated that internet gave the learners the opportunity to communicate immediately with language and offered a great deal of advantages for teaching and learning language. According to Chavez, 1997 , he pointed that in order to develop our students' language performance, media is one of the main ways to improve learners' abilities to learn and work independently, analyze language form, think meaningfully and critically, and solve communication problems. Moreover, more studies showed that using internet and network have positive effects in language learning. Fotos and Browne (2004) indicated that there are large numbers of studies for the past years which

"strongly emphasize the significant role of CALL in developing linguistic proficiency and communicative competence in L2 learners as well as promoting increased levels of learner autonomy, motivation, satisfaction, and self-confidence" (pp. 8-9)

Murphy (1995) explored that using technology and internet have an effect on the learning outcomes in classroom. These outcomes can be subdivided into many fields such as social growth, problem solving, peer teaching, independent work, and exploration. He stated that technology has played an essential role in the field of teaching and learning language. Researchers and linguists have shown that technology integrated into classrooms promote higher-level learning, thinking critically and solve problems skills among students.

Krajka (2000) stated that in English classroom and through online instruction, learners use the authentic natural language materials relating to our real life context. He also stated that on-line instruction could provide a clear picture of learners' performance in the classroom, because when students read about many issues and events happen in the present, they experience the exact problems. He also stated that in order to provide learners with authenticity material, learners should enrich their writing instructions with the internet components. Besides the activities develop all language skills, writing, reading, vocabulary, speaking/conversation, and listening.

Learning about the important use of technology and WWW in schools in general and classroom in particular becomes one of the most issues in educational field. Pelgrum (2001) stated that there are many reason toward the importance of technological media in general and internet in particular. These reasons related to the social and economic interests such as making the school and classroom clever and attractive, living in a technological society., Etc. this is proved that using internet and WWW have positive effects in language education and they create the best opportunity of language learning through the real performance and the increased knowledge 
Using WWW while learning English as a foreign language can enhance students' performance to develop their skills. For example, they can listen to the native speakers who use the native language; they can speak, make conversation, pronounce new words, greet and role play; they can read the texts and instructions, make skim and scan the text; and they can write sentences, paragraphs, essay, instructions, a dialogue script, a journal entry ... etc.

Mc Nabb (2005) asserted that www is one of the most beneficial tools in an educational process when he sets two hypotheses: the first one is that vocabulary building may be supported positively by using reading digital texts. Another hypothesis is based on that use of the internet for guided reading may engage learner more than reading print. Over the last few years, and according to the Jordanian Ministry of Planning and International Cooperation, 2002) stated that Jordan has implemented many educational reform measures to improve the quality of education. These educational reform measures can be briefed on number of issues related to the importance of integration the technology into classrooms, teacher training strategies, emphasis on knowledge economy, modernized curricula, improve teaching, learning and assessment strategies.

Although that using www net are useful in language learning and teaching, because it encourages students to use and practice the language either inside the classroom or outside it, there has been a shortage in its use in the Jordanian classrooms because there are many obstacles such as time pressures (Lam, 2000; Levy, 1997a; Reedet al, 1995), lack of integration the technology into classroom and inadequate training. (AbdalHaqq, 1995; Lam, 2000; Langone et al, 1998; Levy, 1997; Smerdon et al, 2000).

The internet has become as an integral part everywhere and a vital tool of communication, so it is worth investigating exactly how the WWW net fits into the daily lives of our students at educational institutions. EFL students believe and attitudes about web net are critical determinants of their using it toward developing linguistics proficiency. The positive outcomes of web learning are highly correlated to the favorable and positive attitudes toward using it effectively. So in this study, exploring our Jordanian EFL students' attitudes toward using this vital tool to develop their learning (e.g. practicing various language skills, and vocabulary) is very crucial because it allows those language learners to access to a huge amount of authentic language input that enables them to engage in reading, speaking, listening, and writing tasks.

\section{LITERATURE REVIEW}

Braine (1997) conducted a study to investigate the effects of networked computers on ESL student writing at Brock University in Ontario, Canada. The researcher compared between traditional lecture-style class and networked computer class ESL students in first-year English classes writing. The researcher tried to find which setting had more improvement in writing. After the treatment, he scored and analyzed the first and final drafts of students' papers. The results revealed that the networked promotes better writing and more peer and teacher feedback.
Cuban (2001) conducted a survey at Stanford University in 1989 and 1997 to investigate the importance of using overhead projector and VCR in the classroom. The findings revealed that computers are very rarely used during the instructional treatment. He also found that the most teachers do not use computers during class time. Moreover, the results also revealed that the majority of teachers who use computers maintain existing practices of teaching, and few students used technologies at the invention level.

Bataineh and Bani Abdelrahman (2006) investigated the perceptions of EFL students toward their computer literacy. The study sample consisted of 210 EFL students. The findings revealed that the majority of the students are proficient in computer skills such as deleting files, formatting a floppy disk,copying files, and installing a program on a hard disk, while most of them are a little proficient in some computer skills such as using PowerPoint, using images from a camera or digital camera in computers, and creating databases. The results also revealed that there is not significant effect for gender but a significant effect for year of study on students' perceptions of their computer literacy.

Almekhlafi (2006) investigated the effect of CALL on EFL students' achievement. He also tried to investigate the effect of CALL on learners' attitudes towards learning English in the United Arab Emirates. To achieve the purpose of the study, 83 elementary students from Al-Tamayoz Elementary school were participated. Then they were divided into experimental and control groups. The results revealed that the students in the experimental group had a positive attitude towards CALL. The findings also showed that CALL affected students' performance and achievement positively.

Hsu and Sheu (2008) investigated students' attitude toward the use of CALL to improve their English language learning. The researchers created a website at the National Kaohsiung University of Applied Sciences. He chose 373 learners to use the website for three months and then answered a questionnaire. The results revealed that $66 \%$ of the students had used the website. The results also indicated that teachers can design exercises to reinforce students' learning outside the classroom.

Mahfouz and Ihmeidehb (2009) tried to explore Jordanian university students' attitudes towards using video and text chat discourse with anonymous native speakers of English to improve their English language proficiency. To achieve the purpose of the study, the researchers designed a questionnaire. The participants were 320 university students who studied in two Jordanian universities. The findings showed that students had high positive attitudes towards using video and text chat with English native speakers for improving their English language skills. Moreover, results also revealed that there were statistically significant differences amongst students due to their gender, and the faculty they are enrolled in.

Al-Zaidiyeeni, and Fook (2010) investigated the level of Information and Communication Technologies (ICT) use for educational purposes by teachers in Jordanian rural secondary schools. To achieve the purpose of the study, the researchers collected the data through the use of quantitative 
data. Then they distributed a questionnaire to 650 teachers in Jordan randomly. The findings of the study showed that teachers had a low level of ICT use for educational purpose. The results also showed that teachers hold positive attitudes towards the use of ICT.

Alkaraki and Awad (2013) investigated the important use of computers in classrooms. They tried to elicit whether using computers influence the students' attitudes toward learning English language positively or negatively. They also tried to explore if there are any significant differences between these attitudes according to sex and age of the students. The participants of the study were 100 EFL students at Madaba public Schools-Jordan. They were divided into 50 males and 50 females. In order to achieve the purpose of the study, the researcher distributed a questionnaire to the participants of this study. The findings of this study revealed that using computers influence the EFL students' attitudes toward learning English language positively. Moreover, it was found that older students have more positive tendency toward using computer in language learning.

\section{STATEMENT OF THE PROBLEM}

Many researchers such as (Kim, 2002; Teo, 2006) indicated that there is a significant positive correlation between students' attitudes toward www and their performance in the classroom. In other words, those who have more positive attitudes towards computers, the more likely they are to use computers to develop their linguistic proficiency. Liaw (2002) stated that students, who have more positive attitudes toward using computer, can use it successfully.

From her experience, at public Jordanian schools as well as Jordanian national universities, the researcher has noticed that students have different point of views concerning the use of the www in their learning process, some of them are positive while others are negative. Consequently, the researcher expects that students who interact with elements of online programs can improve their oral and written language proficiency. The researcher also believes that negative attitudes toward using www, may be the one of the main factors behind this low performance in learning English as a foreign Language. Besides, both negative and positive attitudes have a strong effect on the success of language teaching and learning and language proficiency.

\section{PURPOSE AND QUESTIONS OF THE STUDY}

This study tried to explore the Jordanian EFL students' attitudes toward using WWW to develop their linguistic proficiency. The study tried to find out answers for the following questions:

1. What are the students' attitudes towards using WWW to improve their linguistic proficiency?

2. Do these attitudes toward using WWW in learning English as a foreign language vary according to gender?

The generalization of the results of the study is limited because this study is conducted on EFL Jordanian students at national university- Ajloun National University- in the academic year 2016/2017.

\section{SIGNIFICANCE OF THE STUDY}

Despite there are many foreign researches investigated EFL learners' attitudes toward technological media for example, Brett, 1996; Davis and Lyman, 1997; Warschauer, 1996a and 1996b, very little studies have been published about students' using www to develop their linguistic proficiency. This study will be helpful for:

1- For teachers: This study aims at providing the teachers with the learners' performance, it gives them a clear picture of their students' weaknesses and strengths in the language proficiency, and to improve their proficiency through using www and computers activities.

2- For students: The website provides students a learning environment for learning foreign language. It exposes them to larger quantities of images, exercises texts and authentic material. Beside, web sites increase learners' awareness of language structure through informative feedback programs.

3- For Curriculum developers: They can make the decisions about which materials are most suited to the needs of their learners and what are the effectiveness of the types of language communicative activities that suite the learners' proficiency level.

\section{DEFINITIONS OF TERMS}

Attitudes: Morris and Maisto, 2005 defined attitudes as "the individual's prevailing tendency to respond favorably and unfavorably to on object". In this study attitude are determined through the EFL learners' answers to the item of the attitudinal questionnaire which the researcher adapted. Computer it is one of the most important technological media especially in field of

Language learning and teaching.

WWW: World Wide Web.

\section{RESEARCH DESIGN}

This section presents the methods and procedures that were used to conduct this study. It includes population and sample of the study, research instruments, procedures, statistical analysis, data collection and data analysis procedures.

\section{Population and Sample}

The researcher had determined the object of the study consisting the population and samples. The explanations on the object of the study are as follow:

According to Best, (1977: 267) "population is any group of individuals that have one or more characteristics in common that are of interest to the researcher. The population might be all the individuals of a particular type or a more restricted part of that group". The population of the study consisted of all the EFL students at the Departments of Curriculum and Instruction and English at ANU in the first semester of the academic year2016/2017. The sample of the study consisted of 40 (21males and 19 females) EFL students. 


\section{Instrument of the Study}

To achieve the main purpose of the study, and when the researcher did not find a reliable and validated questionnaire that can be used to detect the students' attitudes toward using WWW to develop their proficiency, the researcher developed an attitudinal one. A suitable questionnaire was developed through reviewing the related literature (see Appendix A, P.).

\section{Validity of the attitudinal questionnaire}

To measure the validity of the attitudinal questionnaire, a jury of five TEFL specialists in the curriculum and instruction, linguistics and applied linguistics in some of the Jordanian universities, and four colleagues who hold a PH.D from the Department of Curriculum and Instruction at Yarmouk University were asked politely to examine it. The researcher took all their suggestions into consideration when producing the final form of the questionnaire.

\section{Reliability of the attitudinal questionnaire}

To obtain the reliability of the questionnaire, it was computed on a pilot study of 30 students using the test-retest method. The reliability coefficient was computed using Cronbach's Alpha formula. Then, Pearson correlation coefficient was calculated and found to equal $81.7 \%$ which is an acceptable percentage to adopt and apply the questionnaire in the current study.

\section{THE RESULTS AND THEIR DISCUSSION}

This study tries to explore the Jordanian EFL students' attitudes toward using WWW to develop their linguistic proficiency. To make the discussion more convenient, the researcher insures the reliability of the attitudinal questionnaires. Then, the researcher analyzed the collected data and students' responses with SPSS (Statistical Package for the Social Sciences) version 20 in terms of their attitudes and sex variables. Their students' responses were tabulated in tables to make it easy to read and understand the results. This study tried to find out answers for the following questions:
1. What are the students' attitudes towards using WWW to improve their linguistic proficiency?

2. Do these attitudes toward using WWW in learning English as a foreign language vary according to gender?

Table 1 shows that means ranging from $(1.85-2.35)$. The highest mean reached (2.35) with standard deviation (0.86) for item (4) and the lowest means was (1.85) with standard deviation $(0.80)$ respectively, for items (1) and item $(5$, means was $(1.85)$ with standard deviation $(0.74)$ respectively. The total mean reached 2.04 with standard deviation (0.078) by medium agreement.

Table 2 shows that there are statistical significant differences in students' attitudes towards using WWW to improve their listening comprehension due to gender, where " $\mathrm{t}$ " values reached (1.131) by sig (0.256) It was in favor of "male" by mean (2.12) but the mean of female" reached (1.95).

Table 3 shows means ranging from $(1.83-2.03)$. The highest means reached (2.03) with standard deviation (0.92) for item (2). The lowest means was (1.83) with standard deviation (0.81) respectively, for items (3). The Total Mean reached 1.92 with Standard Deviation $(0.08)$ by medium agreement.

Table 4 shows that there are not any statistical differences in students' attitudes towards using WWW to improve their reading comprehension due to gender, where " $\mathrm{t}$ " values reached $(0.070)$ by sig. (0.944). The means are equal between male and female.

Table 5 shows that means ranging from $(1.90-2.28)$. The highest mean reached (2.28) with standard deviation (1.01) for item (4). The lowest means was (1.90) with standard deviation (0.93), (0.78) for item (1) and item (3) respectively. The total mean reached 2.05 with Standard Deviation (0.10) by high agreement degree

Table 6 shows that there is an observed difference between the two means of the students' attitudes towards using WWW to improve their speaking comprehension due to gender, where " $t$ " values reached $(0.820)$ by sig $(0.820)$. It was in favor of "male" by mean (1.99) but mean of "female" reached (1.32).

Table 7 shows means of the items that range from $(1.90-2.15)$ the highest mean reached $(2.15)$ with standard

Table 1. Means and standard deviation for "students' attitudes towards using WWW to improve their listening comprehension" items

\begin{tabular}{|c|c|c|c|c|c|}
\hline \multicolumn{6}{|c|}{ Listening } \\
\hline No. & Items & Mean & $\begin{array}{l}\text { Standard } \\
\text { deviation }\end{array}$ & Rank & $\begin{array}{l}\text { Agreement } \\
\text { degree }\end{array}$ \\
\hline 1 & I prefer the internet than tape recorders in listening classes. & 1.85 & 0.80 & 16 & Medium \\
\hline 2 & Sound is clearer in the internet in listening classes. & 2.03 & 0.73 & 7 & Medium \\
\hline 3 & $\begin{array}{l}\text { I understand everything during the internet classes better than listening to } \\
\text { the teacher }\end{array}$ & 2.13 & 0.94 & 5 & High \\
\hline 4 & $\begin{array}{l}\text { WWW helps me identify the content words when listening is supported } \\
\text { with visual activities }\end{array}$ & 2.35 & 0.86 & 1 & High \\
\hline \multirow[t]{2}{*}{5} & $\begin{array}{l}\text { Listening to the computers is benefit in understanding the main ideas when } \\
\text { supported with visual exercises. }\end{array}$ & 1.85 & 0.74 & 16 & Medium \\
\hline & Total means & 2.04 & 0.078 & ----- & Medium \\
\hline
\end{tabular}


Table 2. Test table independent samples

\begin{tabular}{llccccc}
\hline Variable & Type & Number & Mean & Standar deviation & "t” value & Sig \\
\hline \multirow{2}{*}{ Gender } & Male & 21 & 2.12 & 0.578 & 1.131 & 0.256 \\
& Female & 19 & 1.95 & 0.376 & \\
\hline
\end{tabular}

Table 3. Means and standard deviation for "students' attitudes towards using WWW to improve their reading comprehension" items

\begin{tabular}{|c|c|c|c|c|c|}
\hline \multicolumn{6}{|c|}{ Reading } \\
\hline No & Items & Mean & $\begin{array}{l}\text { Standard } \\
\text { deviation }\end{array}$ & Rank & $\begin{array}{l}\text { Agreement } \\
\text { degree }\end{array}$ \\
\hline 1 & Getting the meaning of words is easy while reading in classes. & 1.88 & 0.69 & 15 & Medium \\
\hline 2 & Digital activities make reading textbooks easier. & 2.03 & 0.92 & 7 & Medium \\
\hline 3 & $\begin{array}{l}\text { In reading course I can comprehend the written text better than when I hear } \\
\text { to it }\end{array}$ & 1.83 & 0.81 & 18 & low \\
\hline 4 & I prefer reading texts from the internet & 1.95 & 0.75 & 9 & Medium \\
\hline \multirow[t]{2}{*}{5} & $\begin{array}{l}\text { Reading texts from computers is more interesting when supported with } \\
\text { visual activities and images. }\end{array}$ & 1.93 & 0.76 & 11 & Medium \\
\hline & Total means & 1.92 & 0.08 & ----- & Medium \\
\hline
\end{tabular}

Table 4. Test table independent samples

\begin{tabular}{llccccc}
\hline Variable & Type & Number & Mean & Standard deviation & "t " value & Sig \\
\hline \multirow{2}{*}{ Gender } & Male & 21 & 1.92 & 0.366 & 0.070 & 0.944 \\
& Female & 19 & 1.92 & 0.355 & \\
\hline
\end{tabular}

Table 5. Means and standard deviation for students' attitudes towards using WWW to improve their speaking comprehension items

\begin{tabular}{|c|c|c|c|c|c|}
\hline \multicolumn{6}{|c|}{ Speaking } \\
\hline No & Items & Mean & $\begin{array}{l}\text { Standard } \\
\text { deviation }\end{array}$ & Rank & $\begin{array}{l}\text { Agreement } \\
\text { degree }\end{array}$ \\
\hline 1 & $\begin{array}{l}\text { Computer offers a good opportunity to speak with educated native } \\
\text { speakers of English }\end{array}$ & 1.90 & 0.93 & 13 & Medium \\
\hline 2 & I can improve my pronunciation through Audio chat with native speakers & 2.15 & 0.83 & 3 & High \\
\hline 3 & $\begin{array}{l}\text { I sometimes feel tense and embarrassment when chatting in English } \\
\text { because I always make grammatical mistakes }\end{array}$ & 1.90 & 0.78 & 13 & Medium \\
\hline \multirow[t]{2}{*}{4} & $\begin{array}{l}\text { Direct Chatting helps me distinguish the spelling differences between } \\
\text { American English and British English }\end{array}$ & 2.28 & 1.01 & 2 & High \\
\hline & Total means & 2.05 & 0.10 & ---- & High \\
\hline
\end{tabular}

Table 6. Test table independent samples

\begin{tabular}{llccccc}
\hline Variable & Type & Number & Mean & Standard deviation & "t'" value & Sig \\
\hline Gender & Male & 21 & 1.99 & 0.584 & 0.820 & 0.417 \\
& Female & 19 & 2.13 & 0.516 & & \\
\hline
\end{tabular}

deviation (0.95) for item (1). The lowest means was (1.90) with standard deviation $(0.74)$ for items $(2)$. The Total mean reached 2.01 with standard deviation $(0.143)$ by medium agreement.

Table 8 shows that there is an observed difference between the two means of the students' attitudes towards using WWW to improve their writing comprehension due to gender, where " $\mathrm{t}$ " values reached (.516) by sig (0.076). It was in favor of female by mean (2.05) but mean of male" reached (1.98).

Table 9 shows that there are no statistical significant differences in using WWW net due to gender in general, where " $t$ " values reached $(0.023)$ by sig $(0.982)$. It was in equal of "Male" by mean (2.01), but mean of "Female" 
Table 7. Means and standard deviation for students' attitudes towards using WWW to improve their writing comprehension items and total means of them $(n=40)$

\begin{tabular}{|c|c|c|c|c|c|}
\hline \multicolumn{6}{|c|}{ Writing } \\
\hline No & Items & Mean & $\begin{array}{l}\text { Standard } \\
\text { deviation }\end{array}$ & Rank & $\begin{array}{l}\text { Agreement } \\
\text { degree }\end{array}$ \\
\hline 1 & $\begin{array}{l}\text { Using keyboards to writ messages, emails or any texts may improve my } \\
\text { writing skills }\end{array}$ & 2.15 & 0.95 & 3 & High \\
\hline 2 & I feel that my writing skill has improved due to the internet activities & 1.90 & 0.74 & 13 & Medium \\
\hline 3 & Internet drove me to search for more on line activities. & 2.05 & 0.71 & 6 & Medium \\
\hline \multirow[t]{2}{*}{4} & $\begin{array}{l}\text { I can improve my skills in using punctuation marks when writing Instant } \\
\text { messaging }\end{array}$ & 1.95 & 0.99 & 9 & Medium \\
\hline & Total means & 2.01 & 0.143 & ---- & Medium \\
\hline
\end{tabular}

Table 8. Test table independent samples

\begin{tabular}{llccccc}
\hline Variable & Type & Number & Mean & Standard deviation & " $t$ " value & Sig \\
\hline Gender & Male & 21 & 1.98 & 0.467 & 0.516 & 0.076 \\
& Female & 19 & 2.05 & 0.468 & & \\
\hline
\end{tabular}

Table 9. Test table independent samples

\begin{tabular}{llccccc}
\hline Variable & Type & Number & Mean & Standard deviation & "t” value & Sig \\
\hline \multirow{2}{*}{ Gender } & Male & 21 & 2.01 & 0.347 & 0.023 \\
& Female & 19 & 2.00 & 0.315 & & \\
\hline
\end{tabular}

reached (2.00). The results of the first question showed that the overall degree of the 'EFL college students' attitudes toward using WWW to improve their linguistics proficiency is moderate with the mean (2.01) and standard deviation (0.103). This result indicates the importance of these attitudes toward using WWW in enhancing the learners linguistics proficiency. Those attitudes should be explored because they are essential factors in determining the teaching and learning efficiency.

Based on the data of the study, it was showed that nearly all of the students confirmed that www is a very useful site to create a rich and meaningful learning environment to them and it offers a great deal of potential advantages for learning and teaching language. The findings of this part of the study are consistent with studies conducted by Almekhlafi (2006) who investigated the effect of CALL on EFL students' achievement. He also tried to investigate the effect of CALL on learners' attitudes towards learning English in the United Arab Emirates. The results revealed that the students in the experimental group had a positive attitude towards CALL. The findings also showed that CALL affected students' performance and achievement positively.

The most frequent skill which our students believe that WWW will improve, which got the highest mean 2.05 with standard deviation (0.10)) by high agreement degree, is speaking skill. Students believe that they could improve their pronunciation through Audio chat with native speakers and Computer offers a good opportunity to speak with educated native speakers of English. The results also showthat Using keyboards to write messages, emails or any texts may improve their writing skills and Internet drove them to search for more activities online. Moreover, www helps them identify the content words when listening is supported with visual activities. It was found that reading texts from computers is more interesting when supported with visual activities and images. The results also indicate that those males and females students are becoming more similar in self-attitudes of using the web site and computer technology to develop their language proficiency.

\section{CONCLUSION AND RECOMMENDATIONS}

The main purpose of this study was to explore the Jordanian EFL students' attitudes toward using WWW to develop their linguistic proficiency. The results revealed that the EFL learners under study either female or male felt that using www enable them to learn the language effectively and efficiently. World wide web net creates a meaningful learning environment to them. The participants in the study show positive attitudes about the importance of using the World wide web net to develop their linguistic proficiency in the four language skills as it gives the opportunity to practice a lot of useful and necessary online activities.

The researcher recommended researchers to carry out future research on learners and teachers perceptions and attitudes toward using different kinds of technology for educational purposes especially on teaching and learning the language skills, integrating the skills, promoting independent learning, developing critical thinking abilities. As conducting such future studies from other researchers would prove the importance and the vital role that WWW could play to develop EFL's linguistic proficiency. 


\section{REFERENCES}

Ajzen, I., \& Fishbein, M. (2000). Attitudes and attitude behavior: Reasoned and automatic processes. In European review of social psychology. W. Stroebe, M. Hewstone, (eds). Wiley, Chichester, England.

Brinton, D. (2004). Nonnative English-speaking student teachers: Insights from dialogue journals. In L. Kamhi-Stein, Learning and teaching from experience (pp. 190-206). Ann Arbor. MI: University of Michigan Press

Eagly, A.H., \& Chaiken, S. (1998). Attitude structure and function. In The Handbook of Social Psychology. D. T Gilbert \& S.T Fiske (eds). McGraw- Hill, Boston.

Fotos, S., \& Browne, C. (2004). The development of CALL and current options. In S. Fotos and C.M. Browne (Eds.), New perspectives on CALL for second language classroom (pp. 3-14). Mahwah, NJ: Lawrence Erlbaum

Gardner, R. C. (1985). Social psychology and second language learning. The role of attitudes and motivation. London: Edward Arnold.

Gardner RC. 2007. Motivation and Second Language Acquisition. PortaLinguarum, 8, 9-20

Hampel, R., \& Hauck, M. (2004). Towards an effective use of audio conferencing in distance language courses. Language Learning \& Technology, 8(1), 66-82. Retrieved 10 October, 2016 from http://llt.msu.edu/vol8num1/hampel

Kim, H. 2002. Teachers as a barrier to technology-integrated language teaching. English Teaching, 57(2), 35-64.

Krajka, J. (2000). Using the Internet in ESL Writing Instruction. The internet TESL Journal, 6(11). Retrieved October 21, 2016 from http://iteslj.org/Techniques/KrajkaWritingUsingNet.html

Lee, W. (2004). Suggestions for revising the $7^{\text {th }}$ National Curriculum of primary English: With respect to the organization of the objectives and contents. Primary English education

Levy, M. (1997a). Computer assisted language learning: Context and conceptualization. Oxford: Clarendon Press.
McNabb,M.L.(2005). Raising the Bar on Technology Research in English Language Arts. ISTE, 38(1). Retrieved October 21, 2016 from http://www.eric.ed.gov/PDFS/ EJ719940.pdf.

Mahboob, A. (2004). Native or nonnative: What do students enrolled in an Intensive English program think? In L. Kamhi-Stein (Ed.), Learning and teaching from experience (pp. 121-149). Ann Arbor. MI: University of Michigan Press

Matsuda, A. (2000). Japanese attitude toward English: A case study of high school students. Unpublished doctoral dissertation. Purdue University, Indiana.

Murphy, V. (1995). Using technology in early learning classrooms. Learning and Leading With Technology, 22(8), 8-10.

Omaggio-Hadley, Alice. (2001). Teaching language in context ( $3^{\text {rd }}$ ed.). Boston: Heinle\&Heinle

Pelgrum, W. J. (2001). Obstacles to the integration of ICT in education: results from a worldwide educational assessment. Journal of Computers \& Education, 37, 163178.

Rossade, K., Heins, B., \& Hampel, R. (2005). Instant messaging in distributed and distance language learning. In P. Kommers\& G. Richards (Eds.), Proceedings of World Conference on Educational Multimedia, Hypermedia and Telecommunications 2005 (pp. 800-807). Chesapeake, VA: AACE. Retrieved 24august, 2017 from http://www.editlib.org/index.cfm?fuseaction $1 / 4$ Reader. ViewAbstract\&paper_id $1 / 420179$

Stern, H.(1983). Fundamental Concept. of Language Teaching, Oxford: Oxford University Press.

Tanguay, E. (1997) English Teachers, Prepare Yourselves for the Digital Age. Teaching English In The Network Age. Retrieved October 21, 2016 from http://userpage.fuberlin.de/ tanguay/english-teachers.htm.

Teo, T. 2008a. Assessing the computer attitudes of students: An Asian perspective. Journal of Computers in Human Behaviour, 24(4): 1634-1642.

Wu K (2010). The relationship between language learners' anxiety and learning strategy in the CLT classrooms. Int. Educ. Stud. 3(1):174- 191 


\section{APPENDIX}

\begin{tabular}{|c|c|c|c|c|c|}
\hline No. & Items & Mean & $\begin{array}{l}\text { Standard } \\
\text { deviation }\end{array}$ & Rank & $\begin{array}{l}\text { Agreement } \\
\text { degree }\end{array}$ \\
\hline \multicolumn{6}{|c|}{ Listening } \\
\hline 1 & I prefer the internet than tape recorders in listening classes. & 1.85 & 0.80 & 16 & Medium \\
\hline 2 & Sound is clearer the internet in listening classes. & 2.03 & 0.73 & 7 & Medium \\
\hline 3 & $\begin{array}{l}\text { I understand everything during the internet classes better than } \\
\text { listening to the teacher }\end{array}$ & 2.13 & 0.94 & 5 & High \\
\hline 4 & $\begin{array}{l}\text { www helps me identify the content words when listening is } \\
\text { supported with visual activities }\end{array}$ & 2.35 & 0.86 & 1 & High \\
\hline 5 & $\begin{array}{l}\text { Listening to the computers is benefit in understanding the main ideas } \\
\text { when supported with visual exercises. }\end{array}$ & 1.85 & 0.74 & 16 & Medium \\
\hline \multicolumn{6}{|c|}{ Reading } \\
\hline 1 & Getting the meaning of words is easy while reading in classes. & 1.88 & 0.69 & 15 & Medium \\
\hline 2 & Digital activities make reading textbooks more easier. & 2.03 & 0.92 & 7 & Medium \\
\hline 3 & $\begin{array}{l}\text { In reading course I can comprehend the written text better than when } \\
\text { I hear to it }\end{array}$ & 1.83 & 0.81 & 18 & Medium \\
\hline 4 & I prefer reading texts from the internet & 1.95 & 0.75 & 9 & Medium \\
\hline 5 & $\begin{array}{l}\text { Reading texts from computers is more interesting when supported } \\
\text { with visual activities and images. }\end{array}$ & 1.93 & 0.76 & 11 & Medium \\
\hline \multicolumn{6}{|c|}{ Speaking } \\
\hline 1 & $\begin{array}{l}\text { Computer offers a good opportunity to speak with educated native } \\
\text { speakers of English }\end{array}$ & 1.90 & 0.93 & 13 & Medium \\
\hline 2 & $\begin{array}{l}\text { I can improve my pronunciation through Audio chat with native } \\
\text { speakers }\end{array}$ & 2.15 & 0.83 & 3 & High \\
\hline 3 & $\begin{array}{l}\text { I sometimes feel tense and embarrassment when chatting in English } \\
\text { because I always make grammatical mistakes }\end{array}$ & 1.90 & 0.78 & 13 & Medium \\
\hline 4 & $\begin{array}{l}\text { Direct Chatting helps me distinguish the spelling differences between } \\
\text { American English and British English }\end{array}$ & 2.28 & 1.01 & 2 & High \\
\hline \multicolumn{6}{|c|}{ Writing } \\
\hline 1 & $\begin{array}{l}\text { Using keyboards to writ messages, emails or any texts may improve } \\
\text { my writing skills }\end{array}$ & 2.15 & 0.95 & 3 & High \\
\hline 2 & I feel that my writing skill has improved due to the internet activities & 1.90 & 0.74 & 13 & Medium \\
\hline 3 & Internet drove me to search for more online activities. & 2.05 & 0.71 & 6 & Medium \\
\hline \multirow[t]{2}{*}{4} & $\begin{array}{l}\text { I can improve my skills in using punctuation marks when writing } \\
\text { Instant messaging }\end{array}$ & 1.95 & 0.99 & 9 & Medium \\
\hline & Total means & 2.01 & 0.103 & ----- & Medium \\
\hline
\end{tabular}

